\title{
Interaction analysis on social-education of Indonesian school students: A literacy activity
}

Rahmad Rafid $^{1 *}$, Farizal Khusnul Khotimah ${ }^{2}$

Master of Educational Policy and Development, University of Muhammadiyah Malang, Malang, Indonesia $^{1^{*}}$

English Department, Islamic institute of Pangeran Diponegoro Nganjuk, Nganjuk, Indonesia ${ }^{2}$ rahmadrafid@ gmail.com ${ }^{*}$, farizalkhusnulsantoso@ gmail.com ${ }^{2}$

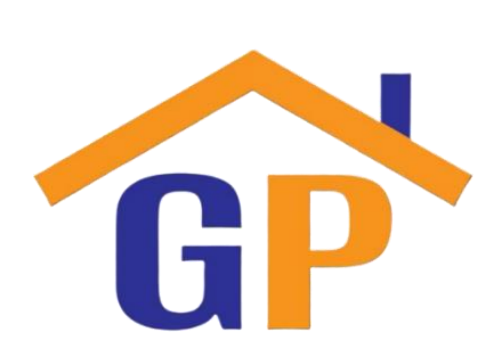

Article History

Received on 8 April 2021

$1^{\text {st }}$ Revision on 30 April 2021

$2^{\text {nd }}$ Revision on 4 May 2021

$3^{\text {rd }}$ Revision on 11 May 2021

$4^{\text {th }}$ Revision on 29 May 2021

Accepted on 14 June 2021

\section{Abstract}

Purpose: The purpose of this study is to analyze the socioeducational interactions between teachers and students. This article also looks at a literacy activity utilized by the teachers and students and their interaction patterns.

Research methodology: This research applied a naturalistic approach and descriptive qualitative research design. The data were collected through observation, interviews, and documentation. The data then were analyzed descriptively using the Miles and Huberman analysis model, namely data condensation, data presentation, and concluding.

Results: The research results show that to improve student literacy, there were two patterns of interaction: first, a one-way interaction pattern centered on the teacher as a facilitator, corrector, evaluator in literacy activities: second, a multidirectional interaction pattern occurred. Literacy activities aim to train the learners' ability in reading, understanding and commenting. During the core activities, several aspects of the interactions occur between teachers and students, such as conveying information, explaining, motivating, and proposing to students. At the closing stage of literacy, several aspects of the interaction between teachers and students occur. Making summaries and reading about the literacy activities have provided directions for further literacy activities and conducting evaluations that have been carried out.

Limitations: There are limitations to the researcher, so this research is limited to one school only with the object of research on all students and teachers assigned to literacy activities at SMA Negeri 1 Latambaga.

Contribution: The study is expected to assist the schools in monitoring the literacy activities and developing student literacy, whereas, for students, this study is expected to improve their literacy and broaden their insights about technological and scientific developments.

Keywords: Social-education interaction, Teachers and students, School literacy

How to cite: Rafid, R., \& Khotimah, F. K. (2021). Interaction analysis on social-education of Indonesian school students: A literacy activity. Journal of Social, Humanity, and Education, 1(4), 269-280.

\section{Introduction}

Literacy learning is an expectation of improving students' reading ability. The literacy learning goals, indeed, cannot be achieved in an instant. Literacy learning requires careful planning and 
programming. On the other hand, schools as a means to develop literacy culture also need thorough planning. The role of schools in fostering a literacy culture is very much needed to improve the literacy of the nation's young generation. Based on a survey conducted by the Program for International Student Assessment (PISA), literacy in Indonesia is very low (Hewi \& Shaleh, 2020). PISA is a knowledge assessment program organized by the Organization for Economic Cooperation and Development (OECD). Conducted every three years, this program is intended for students aged 15 from numerous countries. The results of the PISA study in 2018 released on December 3, 2019, stated that Indonesia's PISA ranking in 2018 fell when compared to that of 2015. This study compares the students' math, reading, and science performance, and the indicators used in this study are the same. The 2015 study surveyed 70 countries, while the 2018 study examined 79 countries (Tohir, 2019). In the categories of literacy facilities, the availability of libraries, newspaper publishing, and printed media, Indonesia ranked second from the bottom of the 61 participating countries (Hewi \& Shaleh, 2020). This indicates that literacy in Indonesia is still very low, mainly in 3 aspects of reading, science, and math.

The PISA study aims to measure the effectiveness of the education system from an international perspective. According to the study, Indonesia consistently achieves a low score in reading literacy. In 2000, the Indonesian reading literacy score was 371 , while in 2003, it was 382. In 2006, the Indonesian literacy score was 393, and in 2009 it was 402. However, the reading literacy score is expected to reach 500. This shows that the reading literacy of Indonesian students is at level 2 of six levels. One of the characteristics of level 2 in PISA, especially Indonesian reading literacy, is that the learners can find one or two pieces of information needed to make inferences or face several conditions. The following characteristic is that students can also be able to determine main ideas, understand relationships, and construct meanings from inference (Harsiati, 2018).

In the era of the industrial revolution 4.0, society entirely utilizes technology as its life-supporting system. Today's learners also use it as a tool to gain knowledge. According to the PISA study results, literacy in Indonesia, in general, is still very low, and its people need to develop their literacy (school literacy, environmental literacy, media literacy, visual literacy, library literacy, and others) through the School Literacy Movement. It is one of the government's programs that seeks to improve the literacy of the millennial generation, mainly to increase their interest in reading and gathering information by developing the habit of reading books beyond school textbooks for fifteen minutes before the lessons begin (Kemendikbud, 2016). The fifteen minutes reading time is based on the Regulation of the minister of education (Permendikbud) number 23 of 2015 on the character development that this is the minimum time to read (Antoro, 2017).

The movement needs continuous guidance to develop a literacy culture with an objective to distance the Indonesian people, especially students or education practitioners, from missing out the accurate information. As an educational institution, schools can develop students' literacy culture through the principal's plans, programs, and policies as the school leader. Establishing a literacy culture is not something instantaneous, yet to start it, the schools require plans, programs, and policies that would be applied by educators (teachers) as the guidelines for the interactions between teachers and students during the learning process and beyond.

Culture is a habit that could be obtained via the learning process. Writing and reading are habitual skills that could be utilized for the nation's future (Suswandari, 2018). The socio-educational interactions between teachers and students would provide much knowledge to students, especially to create a literacy culture. Children could acquire more knowledge during the educational process through interactions at school (Nasution et al., 2019). As the most critical factor during the learning process, the transfer of knowledge from teachers to students is carried out through interactions that form one-way, two-way, even multi-directional communication. Likewise, in providing literacy guidance to students, the teachers should communicate with students. Good teachers-students interaction patterns could trigger the students' learning enthusiasm.

State Senior High School 1 Latambaga is a school located in the Kolaka district of Southeast Sulawesi Province. The school implements a literacy culture policy through the School Literacy Movement program as 
stated in the Principal Decree Number 034/168/2018 on the appointment of Supervising Teachers for the School Literacy Movement for the 2018/2019 academic year. The school mandates the teachers to guide the students' literacy activities. The objectives are to train the students' reading comprehension and generate their reading interest through the literacy culture policy carried out every day at school under teachers' supervision during the time allocated by the school. The teachers' role in this cause is essential. Teachers should prepare fun interaction patterns so that students and teachers could understand each other during the teaching and learning process. The teachers are a substitute for parents when the kids are still at school following the teaching and learning process. The teachers' interaction role is needed to change the students' behavior from initially not wanting to know about something to be curious to know. This behavioral change could improve students' academicism through approaches and interaction patterns to develop their academic abilities.

This study examines social-educational interaction between teachers and students in literacy activities at Senior High School 1 Latambaga. The problems of this research can be described in the following subproblems (1) how the social-educational interaction patterns between teachers and students are during school literacy activities? (2) What are the forms of social-educational interaction patterns between teachers and students during the opening, core, and closing phases at the Senior High School 1 Latambaga?

\section{Literature review Social-educational interactions}

Interaction is an event or particular activity where one entity affects one other entity or more. The interaction may involve two or more physical objects that communicate (Alter, 2018). Social interaction is a social process in which there is a reciprocal relationship between two or more individuals and each of them has an active role and influences each other (Fahri \& Qusyairi, 2019). Routman in Hurst et al. (2013) stated that social-educational interactions during the learning process are critical since they enable the students to learn. Social-educational interactions during the learning process also encourage the teachers to solve complex problems with the easiest solutions.

The teachers are expected to bring social-educational interactions theme to the classroom so the students could learn about the values, rules, and regulations so that every activity they do would be based on values and norms since social interaction is a structured relationship in the form of actions based on social standards and values that apply in a particular community. Social interactions between teachers and students or between students in various situations, contacts, and learning communication demonstrate two-way learning interactions where teachers are teaching subjects and students who are actively learning (Suzanti, 2016). The teachers and students should be mutually active during the educational interactions as an educational interactions process cannot occur when only one side is active. Active in this sense relates to attitude, mentality, and actions (Rizawati \& Sulaiman, 2017).

Interactions between individuals always have certain motives, such as to meet personal needs. Interactions in everyday life can be educative if the participants consciously aim to change one's behavior and actions as their primary objective. Educational interaction should be based on a two-way active relationship with knowledge as its medium so that the interaction would be meaningful and bring creativity. All elements of educational interaction must proceed in the bond of educational objectives. Therefore, educational interaction is a picture of a two-way active relationship between teachers and students in the bond of educational purposes (Subakir, 2017).

\section{School Literacy Movement \\ Philosophical foundation and legal foundation}

The philosophical foundation of the literacy movement is the third point of the youth oath that states "to uphold the language of unity, Bahasa Indonesia," which means the recognition of hundreds of regional languages that have the right to life and the opportunity for the Indonesians to use foreign languages according to their needs. This point emphasizes the importance of language learning in national education. This is also explained in the 1989 UN convention on children's rights to the significance of using the mother tongue, and the 2003 UN convention in Prague on basic literacy skills and practical library skills as the key to literate societies in facing the flow of information and technology (Kemendikbud, 2019). 
The legal basis for the literacy movement in Indonesia :

1. The 1945 Constitution, article 31 paragraph 3 "The government shall endeavor and implement a national education system that enhances faith and piety as well as noble morals to educate the nation's life, which is regulated by law.",

2. Law number 20 of 2003 on the national education system, Law number 43 of 2007 regarding libraries,

3. Government regulation number 32 of 2013 on the Second Amendment to the Government Regulation of the Republic of Indonesia Number 19 of 2005 on National Education Standards.

4. Government Regulation Number 24 of 2014 on the Implementation of Law Number 43 of 2007 on Libraries.

5. Regulation of the minister of education and culture Number 23 of 2015 on the Cultivation of Character,

6. Regulation of the minister of education and culture Number 12 of 2018 on the Amendments to the Regulation of the minister of education and culture Number 22 of 2015 on the Strategic Plan of the Ministry of Education and Culture 2015-2019.

7. Regulation of the minister of education and culture number 21 of 2015 on the Character Culture Movement in Schools,

8. Law of the Republic of Indonesia Number 3 of 2017 on Bookkeeping System (Kemendikbud, 2019)

The government, through the Ministry of Education and Culture, launched a school literacy movement that aims to cultivate and develop student characters to become literate human beings with a literacy ecosystem built through the school literacy movement. In the midst of the Covid-19 pandemic, students are required to stay at home to break the chain of Covid-19 infection. This policy hampered the implementation of school literacy activities initiated by the Ministry of Education and Culture. However, this obstacle did not last long due to several policies issued by the Ministry of Education and Culture to relax the curriculum implementation. Now the teachers are not obligated to complete all basic competencies, but they may choose the basic competencies considered essential.

The literacy module is also a solution issued by the government through the Ministry of Education and Culture to continue to foster a culture of literacy during the Covid-19 pandemic. This digital literacy module is expected to maintain students' and teachers' interests in reading and writing so that school literacy activities can be conducted at home. In concept, the school literacy movement does not only teach students to read and write but also teaches students to master the technology and to know how to utilize it wisely. It is a small step to create big thoughts that begin with literacy. Changes in students' thinking patterns are an expected result of the literacy movement activities. A smart mindset in using knowledge sources during the digital era is very important to filter the information. The basic idea of the literacy concept is the ability to understand written text, which is a skill that starts with the ability to say what is written and understand the text. If these skills are mastered, then the readers can reach a full literacy level, which includes the ability to analyze, conclude, synthesize, and use information and knowledge from the text as a basis for creative thinking and decision making (Prasetyarini, 2017).

Building a literacy culture requires a long and sustainable process. The school literacy movement is the first step to build students' awareness of the importance of understanding the information they receive. Literacy culture can grow since, during learning, students are required to read and then write what they see, hear, and what they think so that they can come up with ideas that can then be developed into higher forms of literacy. To help build a literacy culture, three components act dynamically and sustainably, namely motivation, learning to read and write, and independent reading and writing (Kemendikbud, 2016). These three components are the driving force and encouragement for students in developing literacy culture.

\section{Implementation of the school literacy movement}

School Literacy in the context of the School Literacy Movement is the ability to access, understand and use something intelligently through various activities, including reading, seeing, listening, writing, and or speaking $(\mathrm{CK}, 2016)$. The School Literacy Movement is one of the government's programs implemented by schools to attract parents' attention. This program seeks to realize the habituation of students to love reading. 
If students possess a reading habit, then reading would not be a compulsion but a necessity instead. Starting from a need, reading would become a habit embedded in students (Oktaviani \& Sopiah, 2020).

Since literacy is critical and has a significant impact on Indonesia's progress, then this literacy movement is supposed to be applied at every school level. In 2016, the Ministry of Education and Culture made an innovative literacy activity called the National Literacy Movement. The movement is the implementation from Rule number 23 of 2015 of the Ministry of Education and Culture on growing manners. The National Literacy Movement is divided into some domains, such as School Literacy Movement, Family Literacy Movement, and Society Literacy Movement. This research focuses on the School Literacy Movement. School Literacy Movement is a comprehensive and integrated effort that involves all school members (teachers, students, and parents) and society as parts of the educational environment (Kristiyaningrum \& Ismanto, 2020).

The School Literacy Movement is a participatory business or activity involving school members (students, teachers, school principals, education staff, school supervisors, school committees, parents/guardians of students), academics, publishers, mass media, society (community leaders who can be exemplary, business world representatives, etc.), and stakeholders under the coordination of the Directorate General of Primary and Secondary Education, Ministry of Education and Culture. One of the efforts to make it happen is the development of students' reading habits (Sari, 2018). Implementing School Literacy Movement activities requires the assistance and participation of school residents (teachers, school principals, students, parents, education personnel, school supervisors, and school committees) who are willing to involve actively (Almutmainnah et al., 2017).

The movement's objective is to strengthen the character development movement as outlined in the Regulation of the Minister of Education and Culture Number 23 of 2015. One of the activities in the movement is " 15 minutes reading non-learning books before learning time begins". This activity is carried out to foster students' reading interest and improve reading skills to develop their knowledge. The reading materials for this movement should contain ethical values in the form of local, national, and global wisdom conveyed according to the stages of student development and implemented at every school level. This school literacy movement is officially launched across the nation through three stages of activities, namely: (1) Habit, reading routine activities every day without bills; (2) Development, literacy education activities as extracurricular activities with a specific bill; (3) Learning, literacy education activities integrated into the learning process in the classroom (Silvia \& Djuanda, 2017).

The stages of implementing the school literacy movement are as follows: (1) Increasing interest in reading through 15-minute reading activities (Permendikbud No. 23/2015); (2) Increase literacy skills through activities to respond to enrichment books; (3) Improve literacy skills in all subjects using books; (4) Reading enrichment and strategies in all subjects (Prasetyarini, 2017).

Reading interest cannot just grow instantly. Instead, it needs a long process and stages of change that happen regularly and continuously. Individuals with reading interests will have a passion or a tendency to see and understand the written content, either by reading it aloud or silently. Those people would have a feeling of pleasure as they enjoy the reading activity. Therefore, reading interest is very important for one's development. The development of someone's reading interest forever might not run smoothly due to many factors that could influence it. Especially, at this time when audio-visual resources are easier to access than the written ones. Some studies discovered that the implementation of the School Literacy Movement faces numerous obstacles such as the number of schools that are still inconsistent in carrying out 15-minute reading activities, the lack of books available in the library, and the low participation of teachers (Widodo, 2020). Those obstacles make the implementation of the School Literacy Movement need reinforcement and improvement.

\section{Research methodology}

This research was conducted at State Senior High School 1 Latambaga, Kolaka Regency, Southeast Sulawesi Province, from January to February 2020. This study used a naturalistic approach. The naturalistic approach in qualitative research is research carried out in natural conditions, and the researchers are the key instrument. 
Naturalistic research assumes that the behavior and meaning of a group of humans can only be understood through an analysis of the natural environment (natural setting). This research applied descriptive qualitative research that utilizes qualitative data that is then described and presented descriptively. This type of research is commonly used to analyze an event, phenomenon, or other social situation. Data collection techniques in this study were carried out by observation, interviews, and documentation.

This study analyzed the socio-educational interactions of teachers and students in student literacy activities at Senior High School 1 Latambaga, Kolaka Regency, Southeast Sulawesi. There were two forms of data sources used in this study, namely primary and secondary data sources. Primary data were obtained directly through interviews from informants, while secondary data were gained indirectly from the source. The data analysis used in this research was descriptive. The analysis was carried out interactively and continuously so until the data got saturated. Data analysis was carried out using the Miles and Huberman analysis model, namely data condensation, data display, and conclusion. Data condensation refers to the process of selecting, focusing, simplifying, abstracting, and transforming data that appear in a complete corpus (body) of written field notes, interview transcript documents, and other empirical material (Miles et al., 2014). Data presentation (data display) organizes and presents data in the narrative, table, matrix, or others. In qualitative research, data presentation can be done in a brief description, relationships between categories, and others (Shidiq \& Choiri, 2019).

\section{Results and discussions}

The general problem examined in this study is how to develop social-educational interaction between teachers and students during literacy activities at Senior High School 1 Latambaga. To analyze this problem, the researcher would describe several sub-points that become the focus of this research.

\section{The pattern of social-educational interaction between teachers and students in literacy activities at Senior High School 1 Latambaga}

Social interaction is carried out to shape the social aspects of individuals and groups. Cultivating the social aspects of individuals and groups is essential, especially in educational institutions. School is a place where students and teachers interact with various characteristics. Social interactions that occur at school will form educational interactions that contain communication and relationships among school members as social beings (Nasution et al., 2019). Communication has two elements, namely communicants and communicators. These two elements are connected as they interact with something called a message. Communication that happens during socio-educational interactions is a reciprocal communication between one party and another, while interaction is said to contain education if it consciously aims to educate or lead students to maturity (Anhar, 2013).

This social-educational interaction at Senior High School 1 Latambaga is implemented in the School Literacy Movement program designated for students through teachers' guidance before school hours every day. Through this activity, the teachers can interact with students to foster their interest in reading. The following is a table of student literacy activities at Senior High School 1 Latambaga.

Table 1. Composition of school literacy movement activities for the 2018/2019 academic year (source: data from informants)

\begin{tabular}{|l|l|l|l|}
\hline \multicolumn{1}{|c|}{ Day } & Time & \multicolumn{1}{|c|}{ Type of activity } & \multicolumn{1}{c|}{ Builder } \\
\hline Monday & $\begin{array}{l}07.00- \\
07.30\end{array}$ & Reading Books and Presenting Their Reading Results & $\begin{array}{l}\text { 1. Muthahir, S.Pd } \\
\text { 2. Drs. Krastowo }\end{array}$ \\
\hline Tuesday & $\begin{array}{l}07.00- \\
07.30\end{array}$ & Reading Books and Presenting Their Reading Results & $\begin{array}{l}\text { 1. Syahria Nur, } \\
\text { S.Pd } \\
\text { 2. Nurlaeli, S.Pd }\end{array}$ \\
\hline Wednesday & $07.00-$ & Reading Books and Presenting Their Reading Results & $\begin{array}{l}\text { 1. Natalia } \\
\text { Mangiwa }\end{array}$ \\
\hline
\end{tabular}

2021 | Journal of Social, Humanity, and Education/ Vol 1 No 4, 269-280 


\begin{tabular}{|l|l|l|l|}
\hline & & & $\begin{array}{l}\text { 2. Since Ariaty, } \\
\text { S.Pd }\end{array}$ \\
\hline Thursday & $\begin{array}{l}07.00- \\
07.30\end{array}$ & Reading Books and Presenting Their Reading Results & $\begin{array}{l}\text { 1. Abdullah, M.Pd } \\
\text { 2. Abdul Suaib, } \\
\text { S.Pd }\end{array}$ \\
\hline Friday & $07.00-$ & Reading Books and Presenting Their Reading Results & $\begin{array}{l}\text { 1. Nurhaedah, } \\
\text { S.Pd } \\
\end{array}$ \\
\hline Saturday & 07.30 & & $\begin{array}{l}\text { 2. Dra. Suhartutik } \\
\end{array}$ \\
& 07.30 & Reading Books and Presenting Their Reading Results & $\begin{array}{l}\text { 1. Suparman, S.Pd } \\
\text { 2. Hamdanah, } \\
\text { S.Pd }\end{array}$ \\
\hline
\end{tabular}

Through these activities, schools are expected to increase their students' literacy. From the interaction during these activities, the teachers are expected to provide additional knowledge to students, and both sides could create a literacy culture in schools that could increase their reading interest and train their public speaking skills. This literacy activity is carried out for 30 minutes before learning begins in an open field in the school for all grades. After which, students enter the classroom and carry out educational interactions started by Alquran recital.

Literacy learning in schools is a way to create a school culture that is sensitive to global developments. When interacting during the literacy learning activities, several forms of educational interaction between teachers and students happen. There are three patterns of communication between teachers and students in educational interactions, namely communication as action, communication as interaction, and communication as transaction (Fahyuni \& Istikomah, 2016). The patterns of educational social interactions between teachers and students during literacy activities at Senior High School 1 Latambaga would be explained below.

a. One-way interaction pattern

One-way interaction pattern is teacher-centered patterns of interaction. It happens when the teacher plays a more active role in learning. During the literacy learning process at Senior High School 1 Latambaga, the teachers apply a one-way interaction pattern to start the literacy learning process by giving directions to students about the material they are about to learn, the procedures, and the rules. The teachers implement the pattern by lecturing. The lecture method is chosen due to several factors, such as inadequate learning resources and facilities that hamper the learning process and differences in students' backgrounds and intellectual capacities (Herin, 2016).

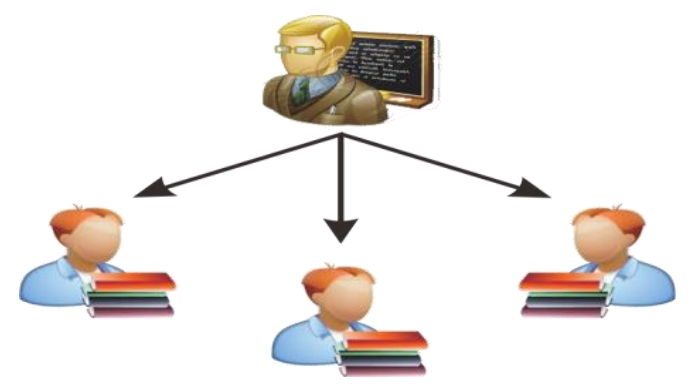

Figure 1. One-way interaction pattern (Sulaiman, 2019)

The one-way interaction pattern in this study is the communication between teachers and students during literacy activities. This interaction pattern happens when students come forward to present their reading material. This activity is meant to measure the level of their understanding. If it is broader than the information available on internet sources, therefore, their literacy level is considered good. 
b. Multi-directional interaction pattern

A multi-directional interaction pattern is a form of communication that involves the whole class where students and teachers build an educational and cooperative atmosphere. Students could discuss and help one another besides also make communication with the teachers. In multi-directional communication, teachers can also apply various methods and learning models (Suriyanti \& Beding, 2019).

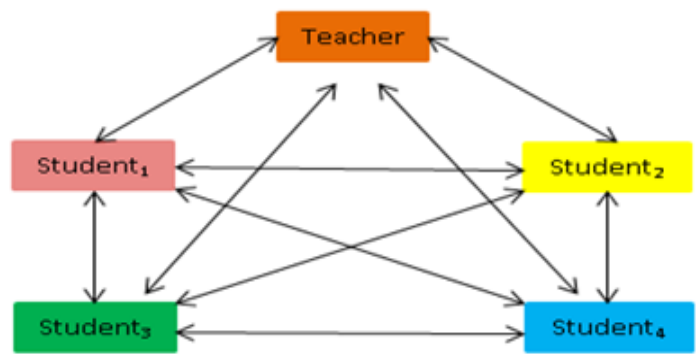

Figure 2. Multi-directional interaction pattern $\underline{(\text { Sulaiman, 2019) }}$

Multi-directional interaction patterns in this study happen when school literacy activities are about to begin. When the teachers communicate with whole classroom members, then at that time, a multi-directional interaction pattern occurs. This interaction pattern also appears in the final stages of literacy activities.

\section{Forms of social-educational interaction between teachers and students when opening, core activities, and closing school literacy activities at Senior High School 1 Latambaga}

The social-educational interactions between teachers and students during school literacy activities at Senior High School 1 Latambaga are the results of preliminary research analysis conducted by the school to examine the problems on-site. During the opening phase of the school literacy activity, the teachers and students conduct several aspects before entering the core activity, such as attracting students' attention to gather on the field, giving directions, motivating, providing references, planning the activity through one-way communication, or lecturing. All students attend this activity under the guidance of one or two teachers as activity companions. After the preparation phase, the teachers direct the students to prepare their books for the core activity.

There is no restriction on the category of the books for the literacy activity. All books and magazines may be used if they are educational. The students are given a day to prepare the books they will present in the next literacy activity. During the opening phase, one student is asked to read aloud in front, and the others should listen and comprehend what is being read. According to Hastuti and Lestari (2018), the most important thing to instill in students is the habituation stage since the school literacy movement aims to develop the students' characters by cultivating the school literacy ecosystem so that they would become lifelong learners (Antasari, 2017). The habituation stage is done by familiarizing students with the habit of coming to school in time and bringing books for this activity. This stage is done to foster students' reading interest and the objectives to be achieved at this stage are as follows:

Table 2. The Students' Objectives

\begin{tabular}{|c|c|c|c|c|c|}
\hline Level & Listen & Read & $\begin{array}{l}\text { Focus of } \\
\text { activities }\end{array}$ & $\begin{array}{l}\text { Type of } \\
\text { reading }\end{array}$ & $\begin{array}{l}\text { facilities and } \\
\text { infrastructure }\end{array}$ \\
\hline Class X & $\begin{array}{l}\text { Listen to the } \\
\text { text } \\
\text { cultivate } \\
\text { empathy }\end{array}$ & $\begin{array}{l}\text { Listening to } \\
\text { the reading, } \\
\text { recognizing } \\
\text { and making } \\
\text { inferences and } \\
\text { predictions of }\end{array}$ & $\begin{array}{lr}\text { Read a book } \\
\text { aloud } \\
\text { silently }\end{array}$ & $\begin{array}{l}\text { Textbooks, } \\
\text { educational } \\
\text { magazines, } \\
\text { newspapers, } \\
\text { and } \\
\text { educational }\end{array}$ & School field \\
\hline
\end{tabular}




\begin{tabular}{|c|c|c|c|c|c|}
\hline & & $\begin{array}{l}\text { what is being } \\
\text { said to foster } \\
\text { empathy }\end{array}$ & & articles & \\
\hline Class XI-XII & $\begin{array}{l}\text { Listen longer } \\
\text { to understand } \\
\text { the reading }\end{array}$ & $\begin{array}{l}\text { Understanding } \\
\text { the reading } \\
\text { content with } \\
\text { more strategies } \\
\text { (recognizing } \\
\text { text types, } \\
\text { making } \\
\text { inferences, } \\
\text { connecting } \\
\text { with daily } \\
\text { activities, etc. }\end{array}$ & $\begin{array}{lr}\text { Read a } & \text { book } \\
\text { aloud } & \text { and } \\
\text { silently } & \end{array}$ & $\begin{array}{l}\text { Textbooks, } \\
\text { educational } \\
\text { magazines, } \\
\text { newspapers, } \\
\text { and } \\
\text { educational } \\
\text { articles }\end{array}$ & School field \\
\hline
\end{tabular}

During the core phase, the teachers perform several tasks, such as conveying information, explaining, motivating, and offering personal opinions on students, and conducting discussions for whole participants. There is also a question and answer session that will improve the students' cognitive capacities and character development to understand and apply what they hear. The teachers should help develop students' habit of allocating spare time to read various books that could benefit them. Character building through fondness for reading from an early age helps improve Indonesian human resources to support the implementation of national development (Wandasari, 2017).

During the closing phase, several activities affect the teachers and student interactions, such as summarizing the main points of the literacy activities, providing directions for the following activities, and conducting evaluations. One of the primary purposes of evaluation is to improve the quality of this program. Evaluation needs to be conducted to see how successful the program in achieving predetermined goals. It is also expected that the inputs from assessment and suggestion forms could be an excellent foundation to improve the implementation of the School Literacy Movement. It is also hoped that there will be changes in the students' quality in reading, writing, obtaining information, and their characters as this program are intended to foster a literacy culture in students through the habituation process as an initial stage (Praptanti \& Ernawati, 2019).

School literacy activities at Senior High School 1 Latambaga positively impact teachers, students, and school in the future. In this digital era, not many people can filter information properly. Therefore, as the educated young generation, they must face the challenges of technological and scientific developments to obtain valid information. This also applies to educational institutions that continuously improve the quality of learning to produce quality graduates.

The school also has developed digital literacy teaching materials as a strategy for the betterment of the school literacy movement program. The researcher discovered that the school had provided facilities and infrastructures in the form of computer laboratories. With those facilities, students can access information from the internet. However, contents related to digital literacy made by schools are very limited, especially the ones developed by the school teachers. To solve this problem, students could access relevant material from the internet.

Digital literacy development also needs to be developed because as a means to support contextual learning where a lot of useful information is presented. It will foster interest in learning since it is a basic concept that helps teachers link the material being taught with the students' real-world situations. It also encourages students to make relationships between the knowledge they have already had with the application in their daily lives. 


\section{Conclusion}

Based on the results and discussion described above, the conclusions of this study are:

1. To improve students' literacy, there are two patterns of interaction: first, a one-way interaction pattern centered on the teacher as a facilitator, corrector, and evaluator in literacy activities, and the second is a multi-directional interaction pattern that occurs between teachers to students and students to students. These interactions aim to provide equal opportunities to demonstrate students' ability to read, understand. and comment.

2. During the opening phase of literacy activities, several aspects of interaction happen between teachers and students, such as attracting students' attention to gather on the field. This activity is carried out outdoor, giving directions, motivating students, providing references, or planning. This activity is a one-way communication or lecture method given by the teacher. Then, during the core phase, several aspects of the interaction happen between teachers and students, such as conveying information, explaining, providing motivation, proposing students' personal opinions, and conducting discussions between students and teachers, students and students. Then at the closing phase of the literacy activity, several aspects of the interaction between teachers and students occur, such as summarizing the main points of reading and the literacy activities they have done, providing directions for further literacy activities, and evaluating their activities just conducted.

\section{Limitation and study forward}

In the process of this research, there are some limitations of the research experienced and can be used as a factor for future researchers to complete the research to be carried out, because of course this research still has shortcomings that need to be improved in further research some limitations of researchers in this study, among others:

1. Research is only conducted in a short period of time. It is hoped that further research can be carried out with a longer period of time to get maximum results.

2. In the data collection process, the information provided by the respondent sometimes does not show the truth, this happens sometimes because of differences in thinking, the respondent's view of the existing problems.

Then, further research is expected to deepen and describe in-depth the social-educational interactions of teachers and students in school literacy activities. In this study, several aspects need to be developed by further researchers:

1. The next researcher is expected to deeply analyze the patterns and forms of educational interactions between teachers and students in literacy activities.

2. Future researchers are expected to develop and innovate forms of school literacy activities so that students would not feel bored with monotonous activities.

\section{References}

Al-mutmainnah, W., Pantiwati, Y., Purwanti, E., Studi, P., Biologi, P., Malang, F. M., Raya, J., No, T., \& Gls, A. P. (2017). Analisis Penerapan Gls ( Gerakan Literasi Sekolah ) Di Smp Negeri 1 Batu. Prosiding Seminar Nasional III, 180-192.

Alter, S. (2018). System Interaction Patterns. IEEE Conference on Business Informatics, August 2016, 1-10. https://doi.org/10.1109/CBI.2016.11

Anhar, H. (2013). Interaksi Edukatif Menurut Pemikiran Al-Ghazali. Jurnal Ilmiah Islam Futura, 13(1), 28. https://doi.org/10.22373/jiif.v13i1.570

Antasari, I. W. (2017). Implementasi Gerakan Literasi Sekolah Tahap Pembiasaan di MI Muhammadiyah Gandatapa Sumbang Banyumas. Jurnal LIBRIA, 9(1), 13-26.

Antoro, B. (2017). Gerakan Literasi Sekolah: Dari Pucuk Hingga Akar.

CK, D. H. (2016). The Implementation of School Literacy Movement in Secondary School. The 4th International Conference On Language, Literature, Culture, And Education, 1-8. https://doi.org/10.2991/icei-17.2018.12

Fahri, L. M., \& Qusyairi, L. A. H. (2019). Interaksi Sosial dalam Proses Pembelajaran. Palapa, 7(1), 149-166. https://doi.org/10.36088/palapa.v7i1.194 
Fahyuni, E. fariyatul, \& Istikomah. (2016). Psikologi Belajar dan Mengajar : Kunci Sukses Guru dan Peserta didik dalam Interaksi Edukatif (I). Nizamia Learning Center. http://eprints.umsida.ac.id/738/2/PSIKOLOGI BLJR-NEW BOOK.pdf

Harsiati, T. (2018). Karakteristik Soal Literasi Membaca Pada Program Pisa. Litera, 17(1), 90-106. https://doi.org/10.21831/ltr.v17i1.19048

Hastuti, S., \& Lestari, N. A. (2018). Gerakan Literasi Sekolah: Implementasi Tahap Pembiasaan Dan Pengembangan Literasi Di Sd Sukorejo Kediri. Jurnal Basataka (JBT), 1(2), 29-34. https://doi.org/10.36277/basataka.v1i2.34

Herin, G. (2016). Pola Interaksi Satu Arah Dalam Proses Pembelajaran Di Kelas Xi Ips Sma Negeri 6 Makassar. jurnal sosialisasi pendidikan sosiologi-FIS UNM, 3(2), 136-142. http://ojs.unm.ac.id/sosialisasi/article/view/2376

Hewi, L., \& Shaleh, M. (2020). Refleksi Hasil PISA (The Programme For International Student Assesment): Upaya Perbaikan Bertumpu Pada Pendidikan Anak Usia Dini). Jurnal Golden Age, 4(01), 30-41. https://doi.org/10.29408/jga.v4i01.2018

Hurst, B., Wallace, R., \& Nixon, S. B. (2013). The impact of social interaction on student learning. Reading Horizons, 52(4), 375-398.

Kemendikbud. (2016). Pedoman Pelaksanaan Gerakan Nasional Literasi Bangsa (Mari Menjadi Bangsa Pembaca).

Kemendikbud, S. G. L. S. (2019). Buku Panduan Gerakan Literasi Sekolah Dasar (2 ed.). Direktorat Jenderal Pendidikan Dasar dan Menengah Kementerian Pendidikan dan Kebudayaan. http://journal.um.ac.id/index.php/jptpp/article/view/11213

Kristiyaningrum, R. K., \& Ismanto, B. (2020). The Evaluation of School Literacy Movement Program in Secondary School. Jurnal Pendidikan Dan Pengajaran, 53(3), 266. https://doi.org/10.23887/jpp.v53i1.24624

Miles, M. B., Huberman, A. M., \& Saldana, J. (2014). Qualitative Data Analysis, A Methods $\begin{array}{lllll}\text { Sourcebook } & (3 & \text { ed.). } & \text { SAGE } & \text { Publications.Inc. }\end{array}$ http://library1.nida.ac.th/termpaper6/sd/2554/19755.pdf

Nasution, A., Rothomi, A., Rahmania, I., Anggraini, P. R., Adawiyah, R., Wulandari, R. T., Rafid, R., \& Mukadar, S. (2019). Sosiologi Pendidikan :Profesionalisme Pendidikan di Sekolah (M.Syahri (ed.); I). CV. Ismaya Berkah Group. academia.edu/42152451/SOSIOLOGI_PENDIDIKAN_Profesionalisme_Guru

Oktaviani, W., \& Sopiah. (2020). The Effect of School Literation Movement on Students' Reading Interest Through Learning Sources. KnE Social Sciences, 2020, 101-116. https://doi.org/10.18502/kss.v4i7.6846

Praptanti, I., \& Ernawati, A. (2019). Evaluasi Pelaksanaan Program Gerakan Literasi Sekolah Di Sekolah Dasar Negeri. Seminar Nasional Hasil Penelitian dan Pengabdian pada Masyarakat IV Tahun 2019 Universitas Muhammadiyah Purwokerto, 289-296. https://doi.org/10.17977/um025v4i12019p045

Prasetyarini, A. (2017). Implementasi Gerakan Literasi Sekolah pada Sekolah Menengah Pertama di Kota Semarang. Jurnal Politik Dan Kewarganegaraan, 396(2), 94-104.

Rizawati, Sulaiman, A. S. (2017). Hubungan antara Interaksi Edukatif Guru dengan Hasil Belajar Siswa Kelas VI SD Negeri 18 Banda Aceh. Ilmiah Pendidikan Guru Sekolah Dasar, 2(1), 113112.

Sari, I. F. R. (2018). Konsep Dasar Gerakan Literasi Sekolah Pada Permendikbud Nomor 23 Tahun 2015 Tentang Penumbuhan Budi Pekerti. Al-Bidayah: Jurnal Pendidikan Dasar Islam, 10(1), 89-100. https://doi.org/10.14421/al-bidayah.v10i1.131

Shidiq, U., \& Choiri, M. (2019). Metode Penelitian Kualitatif di Bidang Pendidikan. In A. Mujahidin (Ed.), Journal of Chemical Information and Modeling, 53(9). CV. Nata Kerya. http://repository.iainponorogo.ac.id/484/1/METODE PENELITIAN KUALITATIF DI BIDANG PENDIDIKAN.pdf

Silvia, O. W., \& Djuanda, D. (2017). Model Literature Based Dalam Program Gerakan Literasi Sekolah. Model Literature Based Dalam Program Gerakan Literasi Sekolah, 4(2), 160-171. https://doi.org/10.23819/mimbar-sd.v4i2.7799

Subakir, A. (2017). Concept Of Educational Interaction In Education: In Sociological Perspective. DIdaktika Religia, 5(2), 381-400. 
Sulaiman. (2019). Menjadi Guru PAI Yang Dirindukan Peserta Didik dalam Kelas. SEMINAR PROCEEDINGS 1st Annual International Seminar on Education, 93-99.

Suriyanti, Y., \& Beding, V. O. (2019). ANALISIS POLA INTERAKSI DALAM PEMBELAJARAN EKONOMI DI SEKOLAH MENENGAH ATAS KECAMATAN SINTANG KALIMANTAN BARAT. Jurnal Ekonomi Pendidikan dan Kewirausahaan, 53(9), 1689-1699. https://doi.org/10.26740/jepk.v6n1.p187-196

Suswandari, M. (2018). Membangun Budaya Literasi Bagi Suplemen Pendidikan Di Indonesia. Jurnal Dikdas Bantara, 1(1). https://doi.org/10.32585/jdb.v1i1.105

Suzanti, T. (2016). INTERAKSI EDUKATIF DALAM PROSES BELAJAR MENGAJAR SOSIOLOGI DI SMA NEGERI 1 BUNGORO KABUPATEN PANGKEP. jurnal sosialisasi pendidikan sosiologi-FIS UNM, 3(2), 1-5. http://ojs.unm.ac.id/sosialisasi/article/view/2376

Tohir, M. (2019). Hasil PISA Indonesia Tahun 2018 Turun Dibanding Tahun 2015. December 2019, 10-12. https://doi.org/10.31219/osf.io/pcjvx

Wandasari, Y. (2017). Implementasi gerakan literasi sekolah (gls) sebagai pembentuk pendidikan berkarakter. JMKSP: Jurnal Manajemen, Kepemimpinan, dan Supervisi Pendidikan, 1(1), 325343. 